\title{
Baltic sprat larvae: coupling food availability, larval condition and survival
}

\author{
Rüdiger Voss ${ }^{1, *}$, Catriona Clemmesen ${ }^{1}$, Hannes Baumann ${ }^{2}$, Hans Harald Hinrichsen ${ }^{1}$ \\ ${ }^{1}$ Leibniz Institute of Marine Sciences, University of Kiel, Düsternbrooker Weg 20, 24105 Kiel, Germany \\ ${ }^{2}$ Institute for Hydrobiology and Fisheries, University of Hamburg, Olbersweg 24, 22767 Hamburg, Germany
}

\begin{abstract}
Eggs and larvae of Baltic sprat Sprattus sprattus L. were collected during 14 cruises covering the spawning season in 2002 in Bornholm Basin. Main egg and larval production was in April, with a second small peak in June 2002. The in situ larval abundance was corrected for transport processes by hydrodynamic model runs. Corrected larval abundance estimates were compared to initial larval production to derive an index of larval mortality. This index suggested a much higher survival of summer- over spring-born sprat larvae, with pronounced differences in survival for larvae $>11 \mathrm{~mm}$. Independent evidence for this survival pattern was gained by measured RNA:DNA ratios in sprat larvae hatched from April to July 2002 and was linked to temporal variability in potential prey abundance. We found higher mean but less variable RNA:DNA ratios in spring- than in summer-born larvae, indicating a strong selection for fast growth in April and May but a less selective environment in June and July. Zooplankton data revealed high naupliar concentrations of Acartia spp. (a key dietary component of sprat) in April and May, but very low concentrations of larger prey items such as copepodites or adults. In contrast, abundance of larger prey increased considerably in June and July. The results suggest that larger sprat $(>11 \mathrm{~mm})$ in April and May 2002 may have been food limited and, therefore, had lower rates of survival, supporting the underlying hypothesis of sizespecific, temporally limited 'windows of survival' linked to the availability of suitable prey.
\end{abstract}

KEY WORDS: Baltic Sea $\cdot$ Sprat larvae $\cdot$ Condition $\cdot$ Food availability $\cdot$ Mortality $\cdot$ Hydrodynamic modelling

Resale or republication not permitted without written consent of the publisher

\section{INTRODUCTION}

Natural variations in the abundance of fish stocks can be the result of several factors acting on all life stages. In particular, factors affecting the early life history stages have been identified as contributing to recruitment variability and, hence, stock abundance (e.g. Cury \& Roy 1989, Fortier \& Villeneuve 1996, Köster et al. 2003).

While survival during the egg phase might be critical in some cases (e.g. Köster \& Möllmann 2000a), emphasis of research has mostly been on the larval stage. Iles \& Sinclair (1982) advocated the importance of variable ocean circulation patterns for larval survival. According to the 'member-vagrant' hypothesis (Sinclair \& Tremblay 1984), cohort integrity and retention of larvae in areas of favourable environmental conditions would be beneficial to larval survival. Food limitation at the time of first feeding was suggested as an important factor regulating recruitment success as early as 1914 by Hjort, who formulated the 'critical period concept'. Cushing (1974) expanded this time period: in formulating his 'match-mismatch' hypothesis, he argued that the temporal coupling or decoupling of the production maxima of fish larvae and their prey organisms comprises the major source of recruitment variability. However, for species living at the limit of their geographic distribution, the spread of spawning over a long period of time might be an adaptation to year-toyear variability in environmental conditions (Cushing 1990), and survivors to recruitment must not necessarily stem from peak spawning periods. Such potential seasonal variations in larval survival success and their relation to larval prey fields are difficult to inves- 
tigate, since they require extensive temporal and spatial coverage of the dynamics of larval and zooplankton abundance.

In the Baltic Sea, the sprat Sprattus sprattus L. represents an example of a species occurring at the northern boundary of its geographical distribution (Muus \& Nielsen 1999), with its spawning period here typically extending from March to August (Elwertowski 1960, Grimm \& Herra 1984). Baltic sprat is of high ecological importance (Rudstam et al. 1994, Kornilovs et al. 2001) both as an important prey for top predators (e.g. cod, harbour porpoise) and as a major predator on zooplankton and fish eggs (Arrhenius \& Hansson 1993, Bagge et al. 1994, Köster \& Schnack 1994, Möllmann \& Köster 1999, Köster \& Möllmann 2000a,b). It is also presently the most abundant, commercially exploited species in the Baltic Sea (ICES 2004), and its management is challenged by large stock fluctuations mainly caused by a highly variable recruitment success.

Baltic sprat spawning stock biomass is only a poor predictor of recruitment (Köster et al. 2003, MacKenzie $\&$ Köster 2004). Recent research has shown that recruitment depends to some degree on temperature conditions influencing gonadal development and egg survival (MacKenzie \& Köster 2004). The critical period in the sprat life cycle is, however, the larval and early juvenile stages (Köster et al. 2003). Mechanisms influencing survival in the larval stage are only poorly understood. Process-oriented investigations are challenged by the long spawning period and the corresponding need to appropriately monitor larval survival and potentially important environmental conditions, such as suitable prey abundance. Survivors may originate from temporally distinct 'windows of survival' which, in the case of food supply, may be determined both by the availability of suitable prey at first-feeding (i.e. copepod nauplii) and the older larval stages. Sprat larvae generally feed on all developmental stages of copepods, mainly Acartia spp. (Voss et al. 2003). However, as they grow, their prey field shifts to larger developmental stages (Voss et al. 2003), and food limitation could also occur through a temporal mismatch of older copepodite stages and larger sprat larvae.

Sprat spawning is concentrated in the deep basins of the Baltic Sea. In the Bornholm Basin, one of the most important spawning grounds (Köster et al. 2001), egg distribution is restricted to its central part, with sprat eggs occurring in the upper part of the halocline, typically between 45 and $55 \mathrm{~m}$. After hatch, sprat larvae migrate to the upper water layers to feed (Voss 2002) and may subsequently be transported away from the spawning grounds. Therefore, direct larval mortality estimates must account for the temporally highly variable transport potential (Hinrichsen et al. 2003a,b), influencing fieldbased larval abundance estimates.

In this study, we investigated seasonal variations in the survival success of sprat in different larval sizeclasses during the 2002 spawning season. Our investigations focused on Bornholm Basin, where seasonally resolved larval abundance and production data and highly resolved zooplankton data were collected. Direct estimates of larval survival up to a specific length were calculated by a combination of field data and hydrodynamic modelling, allowing a correction of field based abundance data. Additionally, independent information on survival probabilities was gained by an indirect biochemical measure, the RNA:DNA ratio. RNA:DNA ratios have been successfully applied to infer growth, condition and survival probabilities in marine fish larvae under laboratory and field situations (e.g. Buckley 1979, 1984, Clemmesen 1994, Clemmesen et al. 1997).

The underlying hypothesis of our work was that sizespecific, temporally limited 'windows of survival' exist and that these are linked to the availability of suitable prey.

\section{MATERIALS AND METHODS}

Field sampling. Seasonal egg and larval abundance: Sprat eggs and larvae were sampled during 14 cruises to Bornholm Basin in 2002 (Table 1). Each cruise covered a standard station grid of 52 stations (Fig. 1). At each station, a double oblique bongo-net haul was

Table 1. Sampling dates (2002) in Bornholm Basin and parameters measured; Vert. distr.: vertical distribution

\begin{tabular}{|lcccccc|}
\hline Season & Date & $\begin{array}{c}\text { Ichthyo- } \\
\text { plankton } \\
\text { abundance }\end{array}$ & $\begin{array}{c}\text { Larval } \\
\text { length } \\
\text { distribution }\end{array}$ & RNA:DNA & $\begin{array}{c}\text { Zoo- } \\
\text { plankton }\end{array}$ & $\begin{array}{c}\text { Vert. Distr. } \\
\text { of larvae }\end{array}$ \\
\hline Winter & 18 Mar & Yes & - & - & - & - \\
Spring & 05 Apr & Yes & - & Yes & Yes & - \\
Spring & 17 Apr & Yes & Yes & Yes & Yes & - \\
Spring & 07 May & Yes & Yes & Yes & Yes & - \\
Spring & 16 May & Yes & Yes & Yes & - & - \\
Spring & 22 May & Yes & - & - & - & - \\
Spring & 18 Jun & Yes & - & - & Yes & - \\
Summer & 04 Jul & Yes & Yes & Yes & - & Yes \\
Summer & 25 Jul & Yes & - & Yes & Yes & - \\
Summer & 16 Aug & Yes & - & - & - & - \\
Summer & 24 Aug & Yes & - & - & - & - \\
Summer & 05 Sep & Yes & - & - & - & - \\
Autumn & 05 Oct & Yes & - & - & - & - \\
Autumn & 14 Nov & Yes & - & - & - & - \\
\hline
\end{tabular}




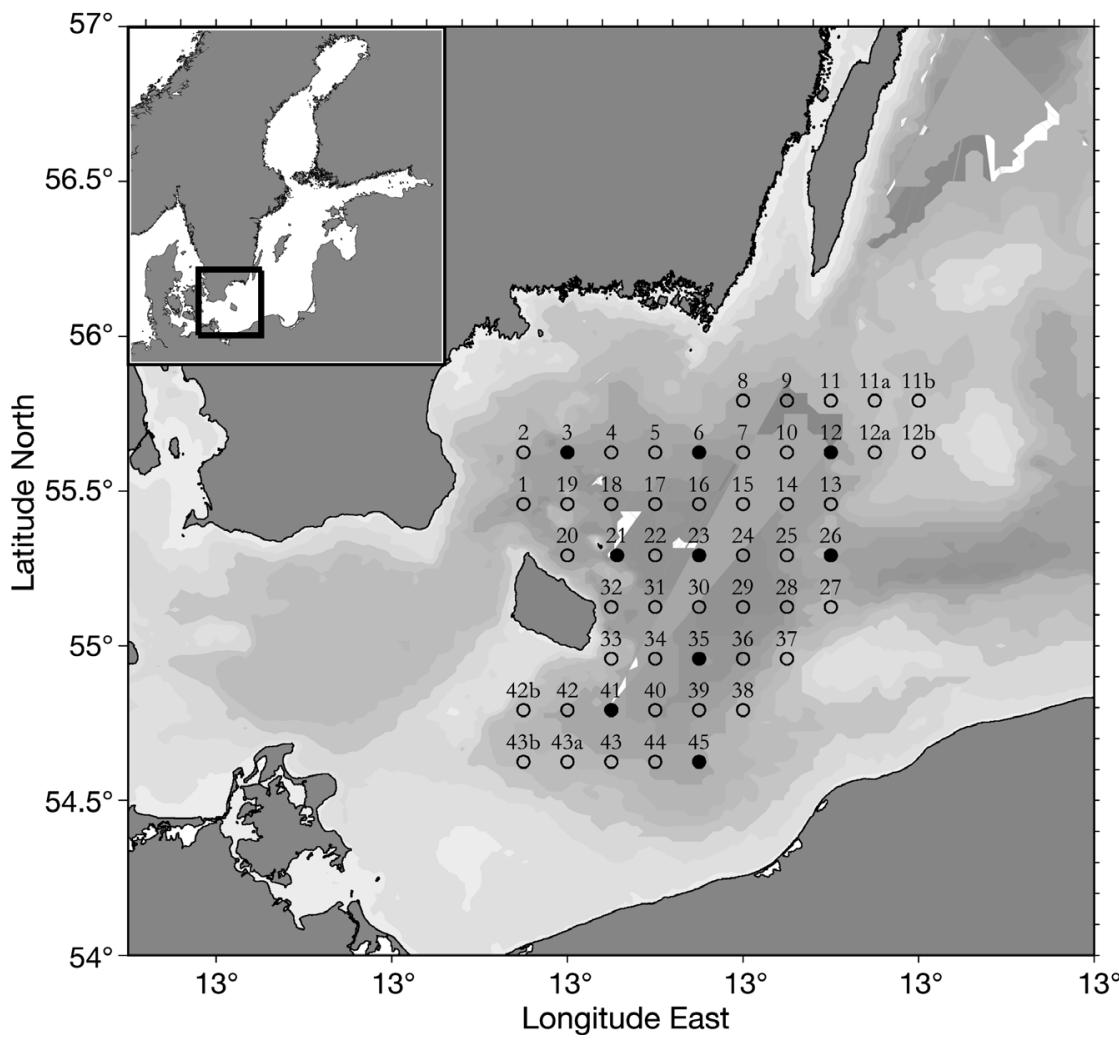

Fig. 1. Bornholm Basin, Baltic Sea. O: standard ichthyoplankton stations; -: stations where additional sampling for larval condition analysis and vertically resolved sampling of zooplankton was carried out

vertical distribution patterns obtained from the research surveys. For sprat eggs, the temperature/stage duration relationships from Thompson et al. (1981) were applied. Integration of the daily production curves yielded seasonal production values for the different egg stages.

From a sub-set of stations (Fig. 1) a random sample of sprat larvae was sorted immediately from the fresh samples and deep-frozen at $-80^{\circ} \mathrm{C}$. These samples were later used for RNA:DNA analyses.

Feeding environment: Prey abundance over the spawning season was estimated by examining the vertical distribution of both the sprat larvae and the zooplankton. The vertical distribution of sprat larvae was determined in June 2002 in the centre of Bornholm Basin (water depth $>80 \mathrm{~m}$ ) using a towed multinet (5 nets; $0.25 \mathrm{~m}^{2}$ opening) with a mesh size of $335 \mu \mathrm{m}$ and equipped with a flowmeter. The multinet was towed at a predetermined depth for $\sim 3$ min at a speed of 3 knots; data from 3 daytime hauls were combined to determine the vertical distribution in the water column with a resolution of $5 \mathrm{~m}$ depth intervals. Sample fixation and analysis in the laboratory were as described for egg and larval abundance.

performed at a ship speed of 3 knots. The bongo $(60 \mathrm{~cm}$ diameter) was equipped with flowmeters in each net. Sprat eggs and larvae were collected from the $335 \mu \mathrm{m}$ net. The samples were preserved on board in a $4 \%$ buffered formaldehyde/seawater solution and were later transferred to formaldehyde-free conservation fluid (Steedman 1976). Fish eggs and larvae were sorted from the samples and staged and measured to the nearest $0.1 \mathrm{~mm}$. A subsample of 100 specimens at least was processed for staging and measuring. The counts were finally standardised to $1 \mathrm{~m}^{2}$ using the volume of water filtered and the maximum depth of the tow ( $\sim 2 \mathrm{~m}$ above the bottom).

Egg staging was performed according to a 4 stage system based on morphological criteria. Stages were chosen according to Thompson et al. (1981), with Stages Ia and Ib combined. For all surveys, the basinwide abundance of the different development stages was calculated by objective analysis (Bretherton et al. 1976). The basin-wide egg abundance for each development stage was then transformed to stage-specific production values using stage duration. As stage duration is temperature dependent, ambient temperatures for the various egg stages were calculated on a monthly basis based on temperature profiles and data on the
Vertically resolved (10 $\mathrm{m}$ intervals) zooplankton abundance estimates were obtained during 5 cruises (beginning of April, end of April, May, June and July 2002) during which samples were taken by a vertically operated multinet with $50 \mu \mathrm{m}$ mesh size. The specimens were counted and identified to species and stage of development, e.g. copepods were classified as (1) nauplii, (2) Copepodite Stages I to III (C I-III), (c) Copepodite Stages IV to V (C IV-V), (3) adult males (C VI-m) or adult females (C VI-f). Stomach content analysis of sprat larvae, covering the spawning season as well as different years, showed that sprat larvae in the Bornholm Basin feed almost exclusively on the various developmental stages of the copepods Acartia spp. (Voss et al. 2003). For the 2002 spawning season, additional prey items were identified. The copepods Centropages hamatus and Temora longicornis were found in smaller proportions in the stomachs (M. Dickmann, Baltic Sea Research Institute, Warnemünde, pers. comm.). All other prey types were generally of minor importance. Therefore, the potential prey abundance was calculated for 2 scenarios: sprat larvae that fed only on Acartia spp. and sprat larvae that fed on Acartia spp., C. hamatus and T. longicornis. 
Seasonal differences in zooplankton abundance and differences in larval abundance over depth were compared with a Kruskal-Wallis test because, even after transformation, the assumptions of normality of distribution as well as homogeneity of variances were not met.

Larval survival. Larval age at length was calculated based on an assumed hatching length of $3 \mathrm{~mm}$ and a daily growth rate of $0.4 \mathrm{~mm}$ (Shields 1989, Munk 1993, Re \& Goncalves 1993, Dulcic 1998, Valenzuela \& Vargas 2002, Huwer 2004) and used to assign agedistributions to different size-classes of field caught larvae. For each $1 \mathrm{~mm}$ length class ( 5 to $<6 \mathrm{~mm}, 6$ to $<7 \mathrm{~mm} \ldots 21$ to $<22 \mathrm{~mm}$ ), the mean hatching date was back-calculated. Larval production at the assumed hatching date was calculated (based on egg production of Egg Stage IV and temperature-dependent stage duration, see first subsection above) and compared to larval abundance in the field. This resulted in the definition of an 'abundance:production ratio' (APRA) of larvae for each length class: APRA $=\ln \left[\left(N_{\mathrm{c}} / N_{\mathrm{h}}\right)+1\right]$, where $N_{\mathrm{c}}$ is the number of larvae caught in the field (for the relevant length class) and $N_{\mathrm{h}}$ is the backcalculated number of larvae hatched (for the relevant length class). High APRA values indicate a high survival of larvae up to the length class in question.

To check the sensitivity of the results to the assumed growth rate of $0.4 \mathrm{~mm} \mathrm{~d}^{-1}$, the calculations were repeated for growth rates of 0.2 and $0.6 \mathrm{~mm} \mathrm{~d}^{-1}$. This also accounted for seasonal variability in near surface water temperature in Bornholm Basin.

As larvae that originally hatched in Bornholm Basin might be advected out of the deep basin and thereby out of the surveyed area, we tried to correct larval abundance estimates for transport losses before calculating the abundance:production ratio. The fraction of these 'lost' larvae was calculated for each backcalculated hatching date as a function of drift duration, using the hydrodynamic model described in the following subsection.

Differences in larval survival between sampling dates were tested using Friedman's ANOVA and an a posteriori Wilcoxon-Wilcox test.

Correction of survival estimates using a hydrodynamic model. Numerical simulations of Bornholm Basin circulation were performed using a 3D, eddy resolving, baroclinic model of the Baltic Sea (Lehmann 1995). The Baltic Sea model is based on the free surface Bryan-Cox-Semtner model (Killworth et al. 1991), which is a special version of the Cox numerical ocean general circulation model (Bryan 1969, Semtner 1974, Cox 1984). The Baltic Sea model covers the whole Baltic, with a horizontal resolution of $5 \mathrm{~km}$ and 60 vertical levels. For the Bornholm Basin region, this results in a vertical resolution of $3 \mathrm{~m}$ layers. A grid size of $5 \mathrm{~km}$ and a time step of 5 min were chosen. Within the Bornholm Basin and partly also in adjacent basins, the model was initialised with 3D hydrographic data (temperature and salinity) obtained during the research surveys. Outside the observational area, the general features of the Baltic were utilised by incorporation of hydrographic characteristics typical for these regions and time periods obtained from previous model runs. For each depth level of the model, observational data were interpolated onto the model grid by objective analysis (Bretherton et al. 1976). The model was forced for all simulations with actual wind data for the entire Baltic provided by the SMHI (Swedish Meteorological and Hydrological Institute). The model was run for $35 \mathrm{~d}$. A total of 144 drifters were deployed over a regularly spaced grid at $>60$ water depth, i.e. the area where peak egg and larval abundance was observed in previous surveys (Voss 2002). Drifters were released at $10 \mathrm{~m}$ depth, but were allowed to randomly move between 5 and $15 \mathrm{~m}$ depth, simulating the vertical distribution of feeding sprat larvae (Voss 2002). Every $6 \mathrm{~h}$ the fraction of drifters outside the $60 \mathrm{~m}$ depth isoline (survey area) was recorded; this fraction was used to correct larval abundance estimates.

Larval condition analysis (RNA:DNA ratio). A total of 589 larvae were analysed for RNA:DNA ratio for April $(\mathrm{n}=236)$, May $(\mathrm{n}=168)$, early July $(\mathrm{n}=100)$ and late July $2002(\mathrm{n}=85)$. Larval sprat samples were freeze-dried to constant weight $(24 \mathrm{~h}$, Christ Alpha 1-4 freezedryer at $-51^{\circ} \mathrm{C}$ ) and were weighed to the nearest $0.0001 \mathrm{mg}$ (Sartorius microbalance SC2). RNA and DNA content was analysed using a modification of the method of Clemmesen (1993) and Belchier et al. (2004). The freeze-dried tissues were rehydrated in Tris-SDS-buffer (Tris $0.05 \mathrm{M}, \mathrm{NaCl}$ $0.01 \mathrm{M}$, EDTA $0.01 \mathrm{M}$, SDS $0.01 \%$ ) for $15 \mathrm{~min}$. Cells were disrupted by shaking in a cell-mill with glass beads of different sizes (diameter $2 \mathrm{~mm}$ and 0.17 to $0.34 \mathrm{~mm}$ ). The resulting homogenate was centrifuged at $3829 \times \mathrm{g}$ at $0^{\circ} \mathrm{C}$ for $8 \mathrm{~min}$ and the supernatant used for analysis. The amount of nucleic acids (DNA and RNA) was measured fluorometrically in a microtitre fluorescence reader (Labsystems, Fluorescan Ascent) using fluorophor ethidiumbromide. To enable determination of the DNA content of the sample, it was necessary to apply an RNAse treatment (Ribonuclease A, Serva) prior to fluorimetric measurement. DNA and RNA content were calculated as $\mu \mathrm{g}$ DNA or $\mu g$ RNA per larva. DNA and RNA concentrations were determined based on calibration curves using lambda DNA and 16S/23S ribosomal RNA (Boehringer Mannheim).

RNA:DNA values plotted in relation to larval length were analysed using the 'Signif program' described in detail by Evans (available at www.dfo-mpo.gc.ca/ 
csas). This programme is useful for analysing distributions where the dependent variable $y$ cannot be expressed as a function of the independent variable $x$, and values of $y$ do not show constant variance. The approach is to calculate the cumulative probability distributions (CPD) of $y$ values that are related to a range of $x$ values. This procedure is repeated along the $x$ scale and the locally estimated CPDs are expressed by their 10th, 50th and 90th percentile along the $x$ scale. The scatter is calculated as the difference between the 10 th and 90th percentiles and then compared to 500 data sets in which the assignment of pairs of variables is randomised. An application of this approach to analysis of RNA:DNA ratios can be found in Pepin et al. (1999).

\section{RESULTS}

\section{Seasonal egg and larval abundance in 2002}

Peak spawning time was in mid-April, with a mean abundance of egg stage I of $152 \pm$ 138 (SD) $\mathrm{m}^{-2}$. A second smaller peak was recorded in June, with nearly $29 \pm 45$ (SD) eggs $\mathrm{m}^{-2}$ for the youngest egg stage. Peak larval abundance was shortly after peak egg abundance in early May 2002 (45 \pm 40 [SD] larvae $\mathrm{m}^{-2}$, Fig. 2a). Temperature-dependent egg development times and the spatial distribution of eggs resulted in basin-wide daily egg production values (Fig. 2b) that generally followed the same pattern as mean abundance. Basin-wide daily egg production of egg stage I reached almost $600 \times 10^{9}$ eggs in the peak spawning period. For egg stage IV (close to hatch), production values at the second peak in June reached $37 \times 10^{9}$ eggs $\mathrm{d}^{-1}$. Additionally, the onset of an unusual winter-spawning event of sprat occurred in November 2002. This unusual event was coupled with abnormally high water temperatures and the good condition of adult sprat at this time of the year (Kraus et al. 2004).

\section{Transport-corrected estimates of larval survival}

Advective loss out of the surveyed area generally increased with increasing drift duration (Fig. 3). Development of the horizontal distribution patterns was, however, highly variable between the different simulated hatch dates. Mean transport losses after $35 \mathrm{~d}$ of drift amounted to $43.6 \pm 12.6$ (SD) \%, with a maximum value of $76 \%$ (hatch $=8$ June) and a minimum of $26 \%$

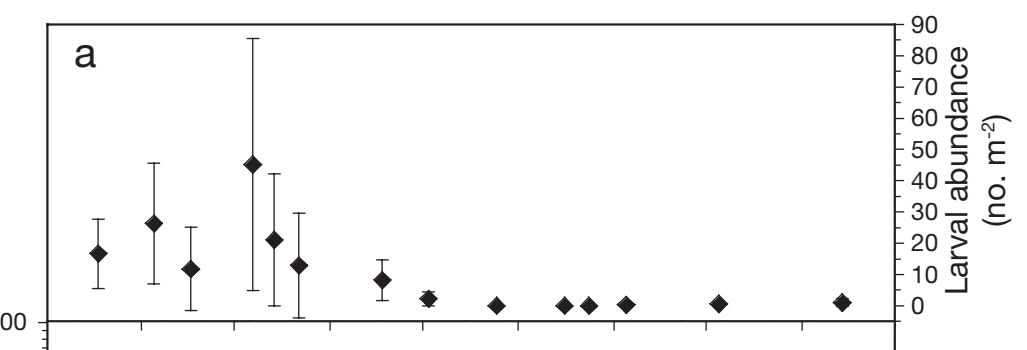

$\rightarrow-$ Egg stage I: SP $35 \times 10^{12}$ O.. Egg stage II: SP $14.3 \times 10^{2}$ $\longrightarrow$ Egg stage III: SP $11.6 \times 10^{12}$ $\rightarrow \cdots$ Egg stage IV: SP $6.8 \times 10^{12}$
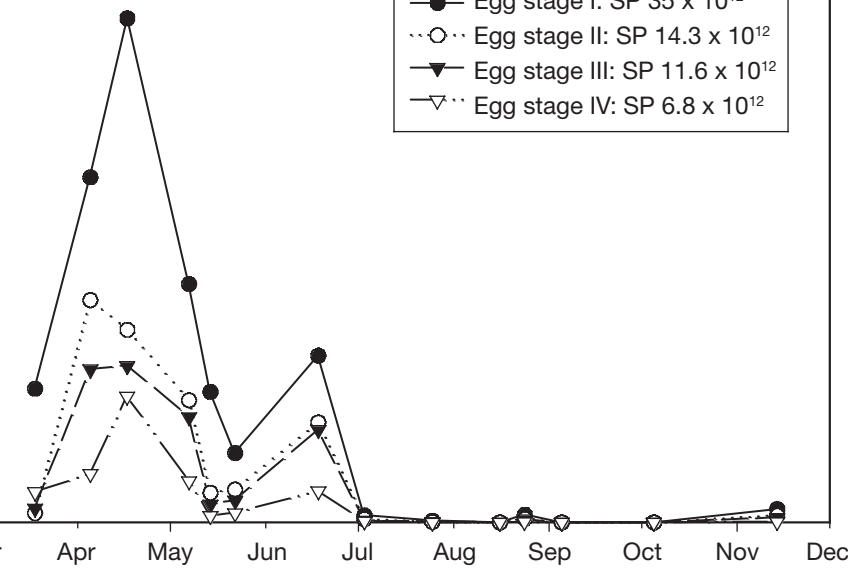
Date

Fig. 2. Sprattus sprattus. Seasonal development of early life history stages n Bornholm Basin during 2002 spawning season. (a) Larval abundance mean \pm SD) for 52 station standard grid. (b) Basin-wide daily egg producof egg stages

(hatch = 29 April). No apparent differences between the hatch dates were obvious up to a drift duration of 20 d. Thereafter, the simulated hatch dates in June indicated higher transport potential out of the area at $>60 \mathrm{~m}$ depth.

Temporally resolved transport estimates were used to correct larval abundance (Fig. 4) before calculating

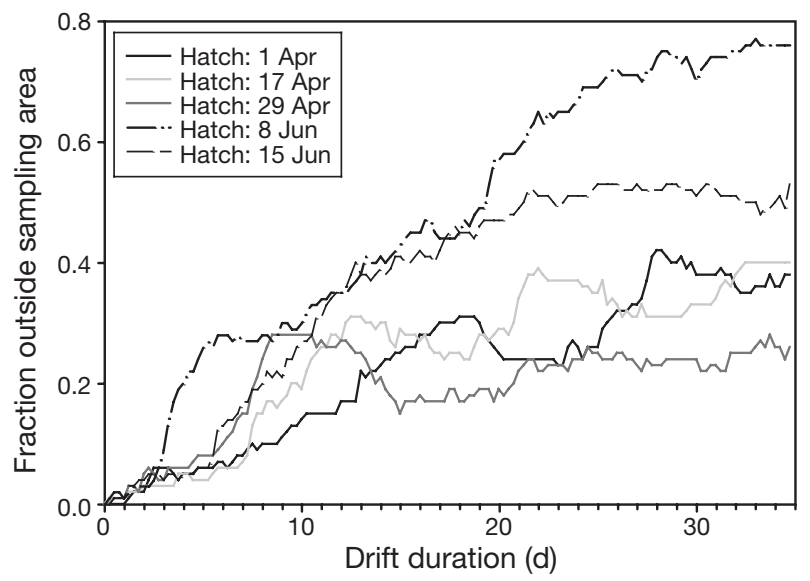

Fig. 3. Simulated transport loss of larval drifters out of surveyed area (>60 m depth), showing temporal development for 5 selected hatch dates 


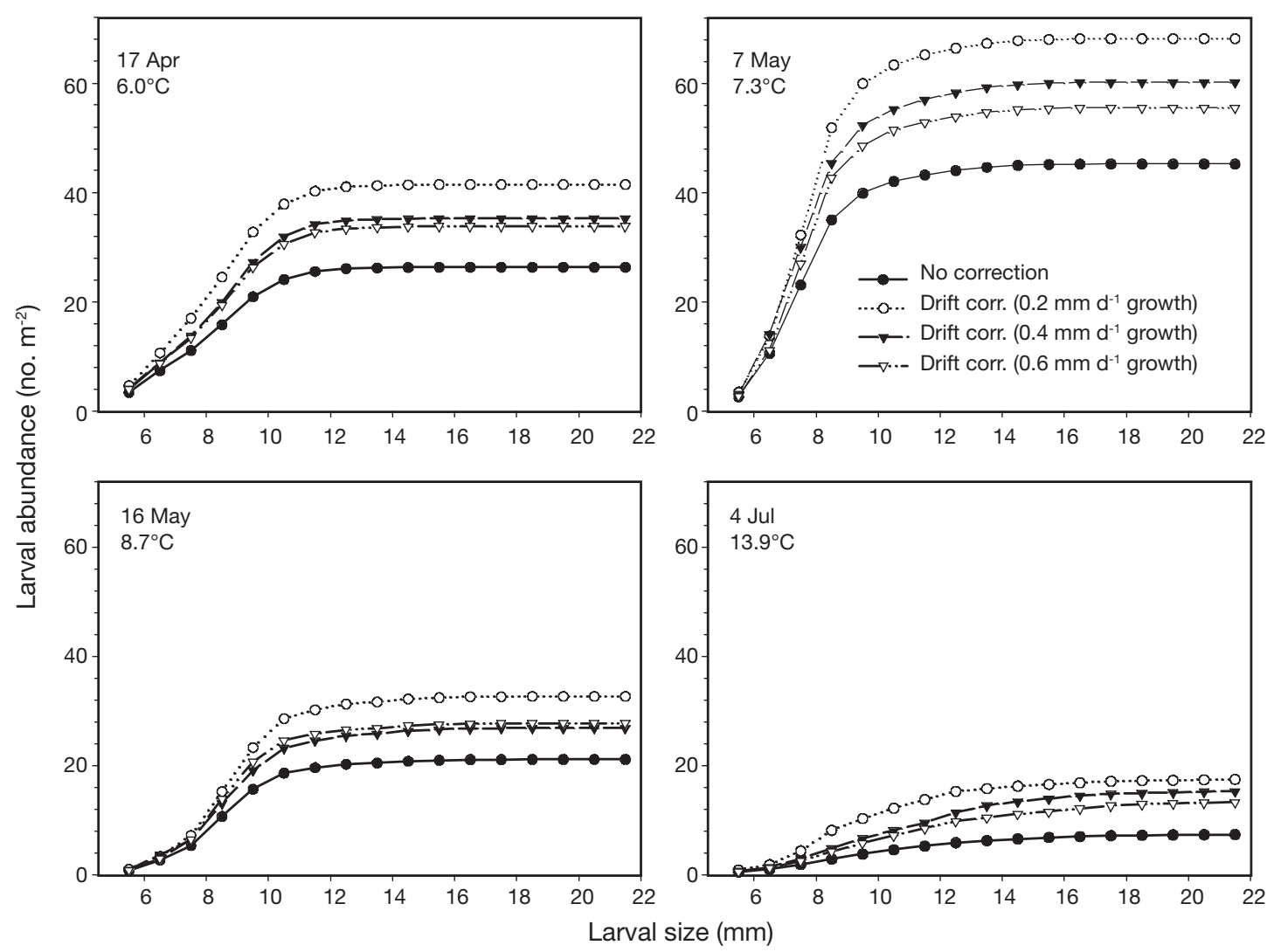

Fig. 4. Sprattus sprattus. Cumulative larval abundance in Bornholm Basin as a function of size for 4 sampling dates. Abundance estimates are given without correction and after correcting for transport losses (drift corr.) assuming a growth rate of 0.2 , 0.4 or $0.6 \mathrm{~mm} \mathrm{~d}^{-1}$

survival estimates. Corrected larval abundance estimates for each larval size-class were higher for assumed slower growth rates, as larval age-at-size and hence drift durations were higher. The strongest change in absolute abundance was for larvae caught on 7 May. Assuming a growth rate of $0.2 \mathrm{~mm} \mathrm{~d}^{-1}$, the corrected cumulative abundance value was 22.95 larvae $\mathrm{m}^{-2}$ higher than to the standard assessment without correction (45.20 vs. 68.15 larvae $\mathrm{m}^{-2}$, Fig. 4). The lowest change in absolute abundance was calculated for larvae caught on 4 July $\left(+10.07\right.$ larvae $\left.\mathrm{m}^{-2}\right)$. Relative changes in cumulative abundance (growth rate of $0.2 \mathrm{~mm} \mathrm{~d}^{-1}$ vs. standard rate) varied between a factor of 1.51 (April) and 2.37 (July).

Assuming a growth rate of $0.4 \mathrm{~mm} \mathrm{~d}^{-1}$, highest values of the abundance:production ratio (APRA), indicative of high survival up to a specific length, were reached by the 7 to $10 \mathrm{~mm}$ size-classes in the April and May samples (2.56 to 2.88; Fig. 5). For larvae caught in July, the highest APRA (2.80) was recorded for the 12 to $13 \mathrm{~mm}$ size-class. For the larger size-classes, APRA generally decreased as larval abundance decreased with increasing size (Fig. 5). In April and May this decrease was more pronounced, with values $<0.1$ for larvae of 15 to $16 \mathrm{~mm}$ in April and 17 to $18 \mathrm{~mm}$ in May. In contrast, APRA stayed above 0.5 for the whole size range of larvae caught in July 2002.

The index revealed no difference in survival up to a larval length of $11 \mathrm{~mm}$ between the different sampling dates (Friedman's ANOVA, df $=3, \mathrm{n}=6$ ). For larvae $>11 \mathrm{~mm}$, survival was significantly higher for June (i.e. caught in early July) than for all other sampling dates (Friedman's ANOVA, p $<0.001$, df $=3$, $\mathrm{n}=11$ ).

When growth rates were set at $0.6 \mathrm{~mm} \mathrm{~d}^{-1}$, absolute values of the APRA changed (Fig. 5), but this did not affect the result of highest APRA values being found in larger, late hatched larvae (July sampling). Again, survival was significantly higher for larval sizes $>11 \mathrm{~mm}$ in the July samples than for all other dates (Friedman's ANOVA, $\mathrm{p}<0.001, \mathrm{df}=3, \mathrm{n}=11$ ). However, when a growth rate of $0.2 \mathrm{~mm} \mathrm{~d}^{-1}$ was assumed for June and July, this period had a similar pattern to April and May, with survival decreasing rapidly for larger size-classes. However, given that the water temperature at 5 to $15 \mathrm{~m}$ depth was highest in July $\left(13.9^{\circ} \mathrm{C}\right.$ compared to 6.0 to $8.7^{\circ} \mathrm{C}$ in April and May), such slow growth rates in July appear unlikely. 

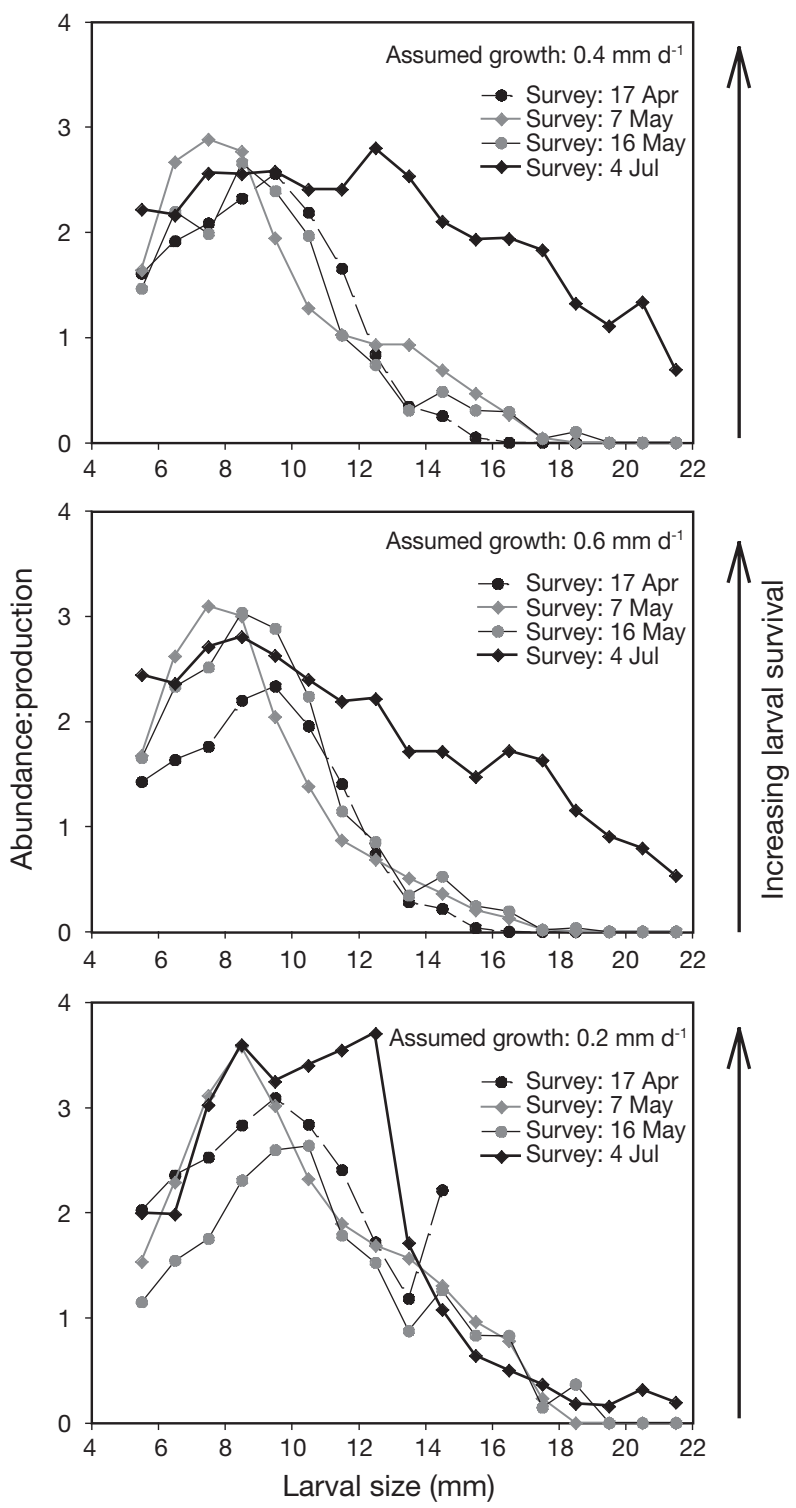

Fig. 5. Sprattus sprattus. Abundance:production ratio (APRA) indicative of survival in relation to size of sprat larvae, assuming growth rates of $0.4,0.6$ or $0.2 \mathrm{~mm} \mathrm{~d}^{-1}$

\section{Condition of larvae in the field}

Mean RNA:DNA values generally increased with increasing larval size on all sampling occasions (Fig. 6a-d). The size range was limited to approx. $\leq 13 \mathrm{~mm}$ length in April and May, but in July larvae $>20 \mathrm{~mm}$ length were also analysed. Medians were higher in April and May for the 4 to $13 \mathrm{~mm}$ size range (Fig. 6e). However, variability in RNA:DNA was higher in June and July than in April and May (Fig. 6f). Mean distance between the 10th and 90th percentiles was 1.122 and 1.171 in April and May, respectively, while it reached 1.635 and 1.660 in June and July (size range up to $13 \mathrm{~mm}$ ). The 90th percentiles did not show large dif- ferences for the overlapping larval size ranges. The 10th percentile, however, increased in April and May from approximately 6.5 to $\geq 7 \mathrm{~mm}$ larval length, whereas it remained almost constant at its initial level in June and July. In contrast to June and July, in April and May no larvae caught had RNA:DNA values indicative of slower growth and/or under-average condition.

\section{Relation of condition and survival to available prey}

The depth range surface to $30 \mathrm{~m}$ encompassed almost $95 \%$ of the larval distribution. The mean abundance of feeding larvae (>6 mm) was highest at $10 \mathrm{~m}$, followed by $5 \mathrm{~m}$ depth (Fig. 7). All deeper investigated depth layers had considerably lower mean values, but statistically significant differences between depths layers could not be detected due to high variability between samplings (Kruskal-Wallis $H$-test, $\mathrm{p}=0.08$ ). We calculated potential prey abundance for the 0 to $30 \mathrm{~m}$ water layer from vertically resolved zooplankton samples. In the first feeding scenario, which only considered Acartia spp. as prey, there was a high abundance of nauplii in April (Fig. 8a). In mid-April, Acartia spp. nauplii abundance was significantly higher than in May and July, but not different from that in June (Kruskal-Wallis $H$-test, $\mathrm{p}<0.01)$. The available prey biomass was, however, low in April, as only very small numbers of Acartia spp. copepodites and adults could be found. In May and (especially) June, a strong increase in numbers of Acartia spp. copepodites and adults was recorded (Fig. 8a), resulting in a significantly higher abundance of Copepodite Stages I to III in June compared to early April or late July (Kruskal-Wallis $H$-test, $\mathrm{p}<0.01$ ). The abundance of older developmental stages of Acartia spp. (C IV to adult) was also higher in June than on both April sampling dates.

The general seasonal pattern was very similar for the second feeding scenario (Fig. 8b). When Acartia spp., Centropages hamatus and Temora longicornis were incorporated as prey, the peak in nauplii abundance in mid-April was even more pronounced. Nauplii abundance in mid-April was significantly higher than in early April, May and June (Kruskal-Wallis H-test, p < 0.01). Results for Copepodite Stages I to III and older developmental stages were similar to the first feeding scenario.

\section{DISCUSSION}

In Baltic sprat, the larval stage has been shown to be critical for reproductive success, while survival is generally less critical once an individual has reached the juvenile (0-group) phase (Köster et al. 2003). In this 


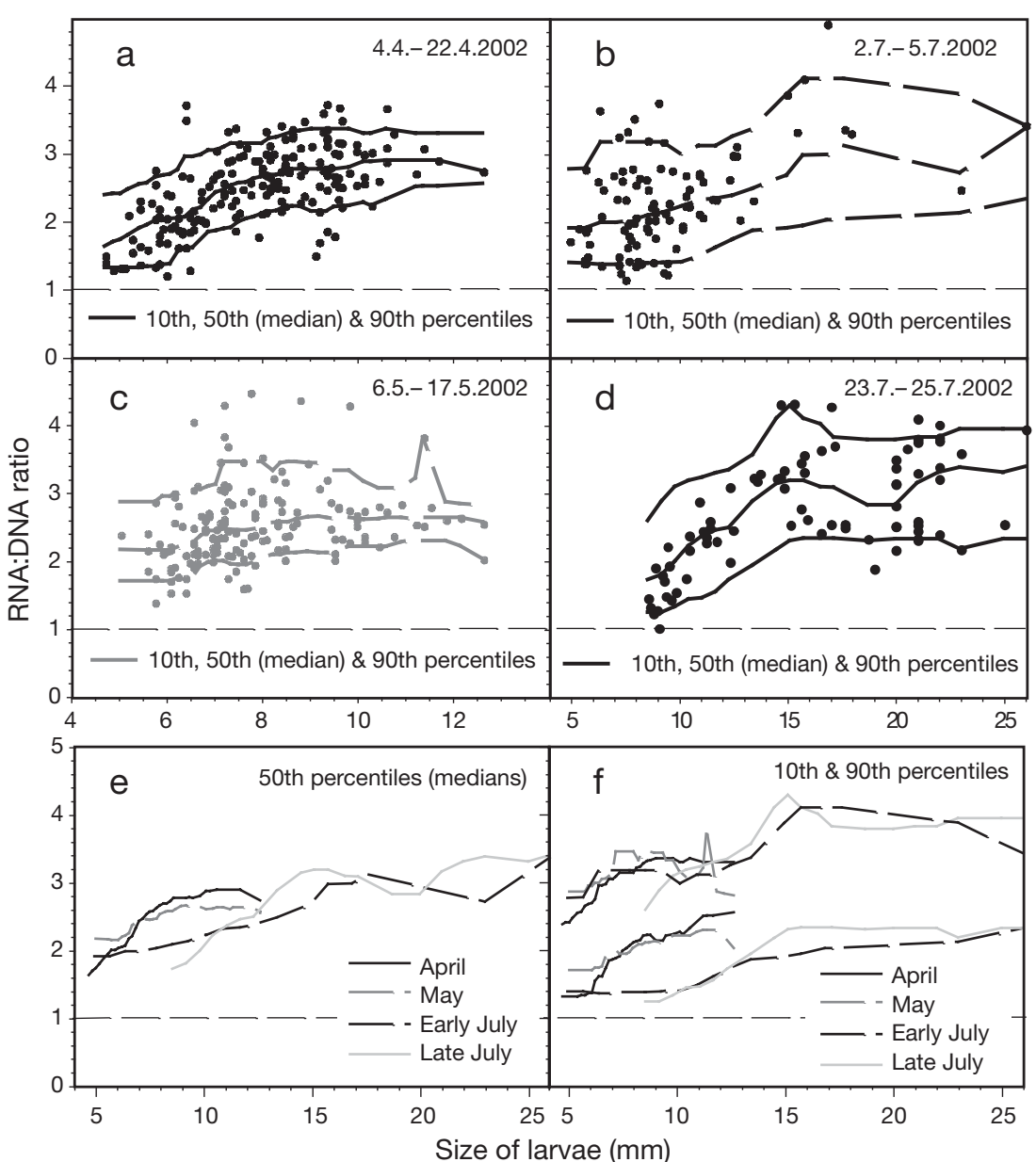

Fig. 6. Sprattus sprattus. Cumulative probability distributions of RNA:DNA content in relation to larval length (Evans, available at www.dfo-mpo.gc.ca/ csas). (a-d) median, 10th and 90th percentiles of RNA:DNA ratios during 4 cruises in 2002; (e,f) comparison of (e) medians and (f) 10th and 90th percentiles. Data below RNA:DNA reference line $=1$ indicate negative growth (Peck et al. 2004)

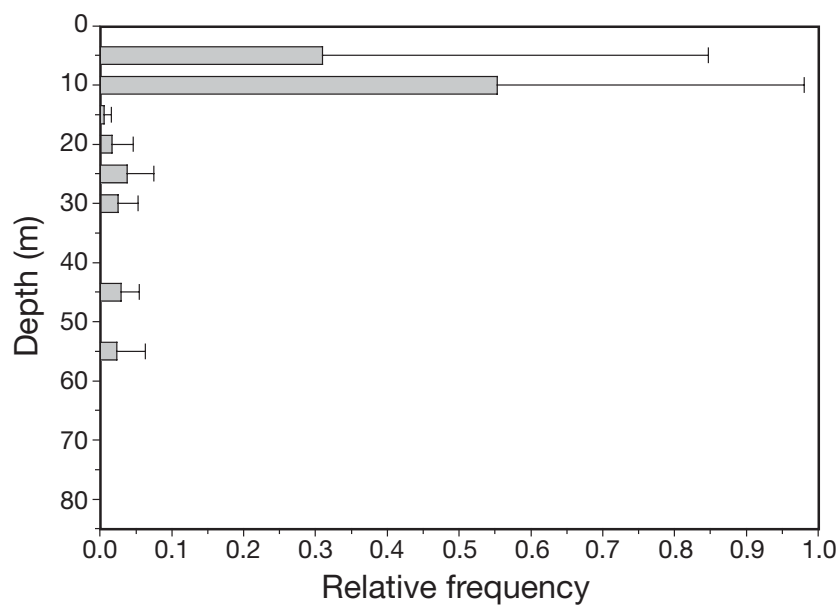

Fig. 7. Sprattus sprattus. Vertical distribution of larvae $>6 \mathrm{~mm}$ length in June 2002. Mean + SD of 3 profiles during daylight hours study, we found evidence for seasonal variations in sprat larval survival over the spawning season 2002. In particular, the survival of larvae $>11 \mathrm{~mm}$ (i.e. not related to first feeding success) showed pronounced differences between peak (April) and late (June) spawning periods and was linked to prey availability.

Spawning activity of sprat in Bornholm Basin is usually spread over a long period, from March to August. Historically, the peak spawning time has been recorded around the end of May (A. Makarchouk, Latvian Fisheries Research Agency Riga, pers. comm.), with yearto-year variability depending to a certain extent on temperature conditions (Elwertowski 1960, Grimm \& Herra 1984). The main spawning peak in April 2002 was early compared to that in other years, but was followed by a secondary, smaller peak in June, which corresponds better to the historical data. For Baltic cod an overall shift in spawning time was recorded in the 1990s (Wieland et al. 2000), but corresponding information on sprat is still too sparse to judge if spawning time has generally shifted to earlier months, or if the 2002 season was an exception.

Our conclusion of higher survival of late spawned larvae is based on abundance:production ratios indicative of relative survival success. Using a 3D hydrodynamic model, larval abundance was corrected for transport out of the surveyed area prior to calculation of the ratios. Corrections relied on the assumption that the modelled drift of passive particles was representative of the average drift of sprat larvae. It is well known that the flow patterns in the Bornholm Basin region are highly complex, being mainly determined by the ephemeral character of wind stress, the baroclinic mass field and the complicated bottom topography (e.g. Lehmann 1995). However, the Baltic Sea model has already been successfully utilised to simulate the drift of larval fishes in Bornholm Basin (Voss et al. 1999, Hinrichsen et al. 2002), including transport correction of abundance estimates for larval cod (Voss et al. 2001), as well as longer term (>35 d) drift simulation of sprat larvae (Baumann et al. 2004). Since the investigated domain was quite large, it was important that the initial distribution of simulated drifters matched the observed larval distribution. Simulated drifters were deployed in a regular spaced grid at $>60 \mathrm{~m}$ water depth. Although horizontal variability 


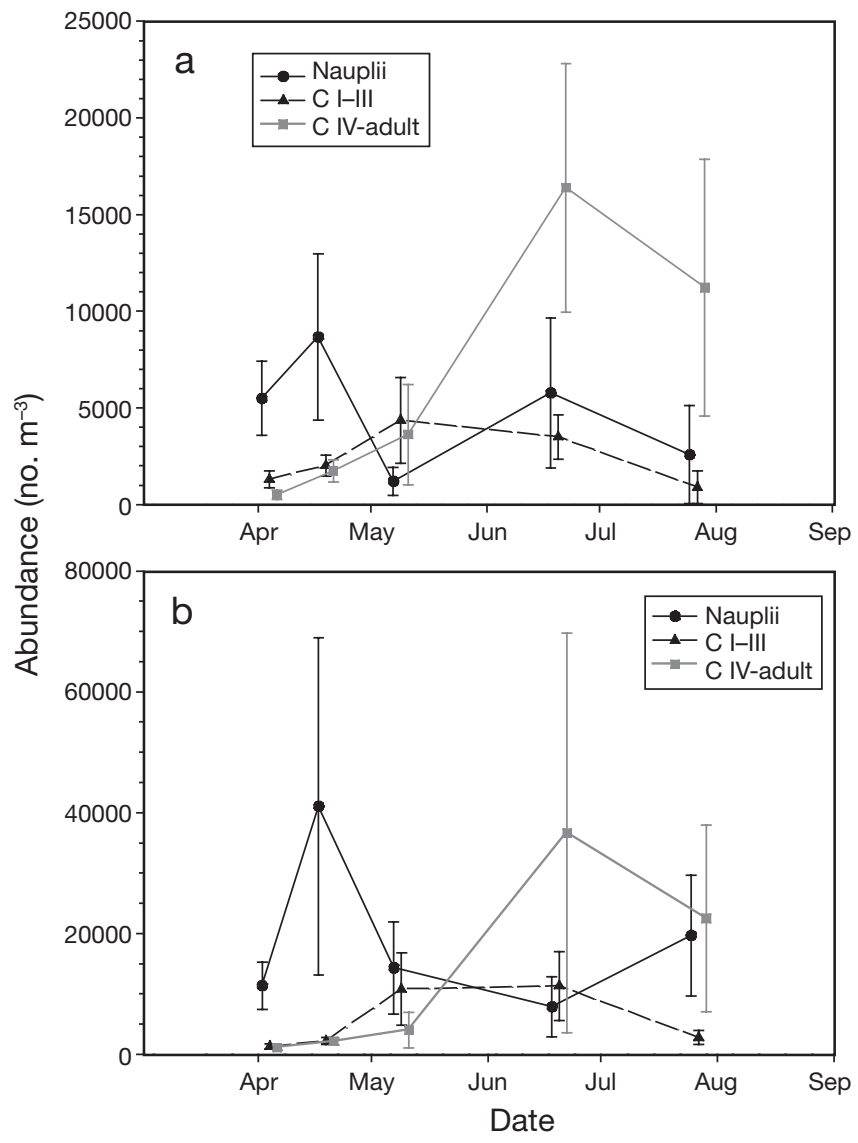

Fig. 8. Mean $( \pm \mathrm{SD})$ abundance of larval sprat prey in Bornholm Basin at 0 to $30 \mathrm{~m}$ depth. (a) Acartia spp. alone; (b) Acartia spp., Centropages hamatus and Temora longicornis

in larval abundance was quite high (see high standard deviation in Fig. 2), the overall distribution of field caught eggs and larvae and drifters matched well.

To determine initial larval production over the spawning season, age-at-length of larvae was calculated based on assumed growth rates. The use of otolith microstructure analysis, currently the best tool for reconstructing past variations in larval fish growth, could have improved the accuracy of growth estimates. Unfortunately, no such samples were available. However, the range of assumed growth rates of 0.2 to $0.6 \mathrm{~mm} \mathrm{~d}^{-1}$ corresponds well with the range of observed growth rates in the field (Shields 1989, Munk 1993, Re \& Goncalves 1993, Dulcic 1998, Valenzuela \& Vargas 2002, Huwer 2004). Positive anomalies in mean growth rates of $0.4 \mathrm{~mm} \mathrm{~d}^{-1}$ were related to higher ambient temperatures, a fact also recorded by Alshut (1988) in laboratory experiments. Therefore, the only inconclusive scenario in our work (lowest growth rates of $0.2 \mathrm{~mm} \mathrm{~d}^{-1}$ in July-caught larvae), seems highly unrealistic. All other investigated scenarios point to a critical period in sprat larval survival for larger larvae (>11 mm).
While sufficient nauplii availability has been shown to be vital for survival of first feeding cod larvae (Hinrichsen et al. 2002), the critical period for larger sprat larvae may be linked to a shift in prey requirements as the larvae grow. At 10 to $12 \mathrm{~mm}$ length, sprat larvae increasingly depend on older copepodite stages and adults (Voss et al. 2003), whereas at smaller lengths they mainly feed on nauplii. It appears possible that larval survival in 2002 was critically dependent on a match between high abundance of suitable copepodite and adult stages and larger larvae and not on a match between nauplii and small larvae.

Based on the hypothesis that RNA:DNA reflects the feeding environment of larvae (Pepin et al. 1999, Clemmesen et al. 2003, Evans available at www. dfo-mpo.gc.ca/csas), there was evidence of different feeding scenarios during the course of the spawning season 2002. The feeding environment for small, firstfeeding larvae was best in April and May, with high abundances of nauplii, whereas for larger sprat the situation was much better in June and July in terms of both biomass and stage composition of their prey. Both feeding scenarios were reflected in the condition analysis and survival probability. Larvae seemed to survive up to large sizes even with comparably low RNA:DNA values in July, suggesting a less selective environment at this time. Not only the fast growing, over-average conditioned larvae survived, but slower growing larvae were also successful. In contrast to this, in April and May environmental conditions seemed to strongly select for fast growing larvae. Larvae in lower nutritional condition were removed from the population (i.e. higher mortalities), as reflected by a rise in the 10th percentile. The majority of survivors in 2002 presumably reflects an environment that was less selective for well-conditioned larger larvae. This is in line with an hypothesis originally proposed by Meekan \& Fortier (1996), whereby during periods of abundant food supply, the selective pressure for fast growth is relaxed, such that slow-growing larvae survive in larger proportions.

In the present study, larvae for RNA:DNA analysis were sampled both night and day, and no differentiation in relation to sampling time was made. Although Chicharo et al. (1998) apparently demonstrated diel variation in RNA:DNA ratios in Sardina pilchardus larvae off the North of Spain, with higher RNA:DNA ratios at night, there is some controversy in the literature regarding this effect. Bailey et al. (1995) found no significant diel effect in Theragra cahlacogramma larvae; Rooker \& Holt (1996) found diel changes in RNA:DNA ratios, with higher values during the day. So far no general pattern has been demonstrated, and if there are any effects, then these would differ according to species and to temperature experienced. In 
general, a sudden increase in RNA concentrations as a response to increased food availability is not possible, since this first leads to increased RNA activity followed by increased RNA amount. Therefore RNA:DNA ratios do not reflect any increase in prey availability over a period of hours (Clemmesen 1994, 1996). A diel signal in the RNA:DNA ratio could therefore arise from size effects, higher consumption rates, RNA:DNA from the food organisms ingested, vertical distribution patterns and temperature regimes. We believe that diel periodicity based on an endogenous rhythm has still to be confirmed under controlled conditions, and is not relevant to the present study.

Our results suggest that high mean RNA:DNA is not always indicative of high survival at the population level. This does not negate the assumption that high RNA:DNA ratios are coupled with fast growth and high survival probability at the individual level. However, at the population level, a less selective environment would be indicated by a broader range of RNA:DNA values and a lower mean. Examination of the distribution of condition factors is necessary to correlate the results with survival.

Besides starvation, predation or changes in larval transport may well determine the survival of early life history stages of fishes (predation: Sissenwine 1984, Köster 1994, Köster \& Schnack 1994; transport: Iles \& Sinclair 1982, Sinclair \& Tremblay 1984, Hinrichsen et al. 2002). Adult Baltic herring and sprat strongly prey on fish eggs, including sprat (Köster et al. 2001). Predation on larvae is, however, only of minor importance, as prey and predator are vertically separated. Adult clupeids feed within and below the permanent halocline (Köster \& Möllmann 1997), while sprat larvae are distributed near the surface. Also, other potential predators on larval sprat (e.g. medusae) have been shown to have a negligible impact (Barz \& Hirche 2004). Different transport scenarios might influence larval survival probabilities through horizontal differences in levels of primary production, and hence food abundance (Cushing \& Walsh 1976, HELCOM 1993, Ochocki et al. 1995) or increased predation risk in shallow water areas due to higher abundance of, for example, 0-group cod. A time-series analysis of transport potential and sprat recruitment did indeed show a positive correlation between retention in the deep basin and good year-class strength (Baumann et al. 2004), although the underlying processes are not fully understood.

In conclusion, we can state that size-specific, temporally limited 'windows of survival' existed during the course of the 2002 spawning season. These were linked to the availability of suitable prey for larger sprat larvae. These results are along the lines of Cushing's 'match-mismatch' hypothesis (Cushing 1974, 1990), but define seasonal variability in survival rather than year-to-year variability. Instead of a first-feeding limitation, larval survival in 2002 depended on a match of older sprat larvae and higher concentrations of suitable prey organisms. However, year-to-year recruitment variability may also be influenced by the temporal overlap of larval production and a window of survival, which is itself determined by zooplankton abundance and stage composition.

Acknowledgements. We thank all the people involved in sampling and analysing the material. Especially, we thank $\mathrm{H}$. Mempel for support with the RNA:DNA analysis, all students participating in the research cruises, and the ships' crews aboard RV 'Alkor', RV 'Heincke' and RV 'A von Humboldt'. The manuscript was considerably improved by 3 anonymous referees. A very special thanks to all participants in the GLOBEC Germany project for creating a nice working atmosphere. The work was conducted under the frame of the GLOBEC Germany project, with financial support from BMBF.

\section{LITERATURE CITED}

Alshut S (1988) Daily growth increments on otoliths of laboratory-reared sprat, Sprattus sprattus L., larvae. Meeresforsch 31(1):23-29

Arrhenius F, Hansson S (1993) Food consumption of larval, young and adult herring and sprat in the Baltic Sea. Mar Ecol Prog Ser 96:125-137

Bagge O, Thurow F, Steffensen E, Bray J (1994) The Baltic cod. Dana 10:1-28

Bailey KM, Canino MF, Napp JN, Spring SM, Brown AL (1995) Contrasting years of prey levels, feeding conditions and mortality of larval walleye Pollack Theragra chalcogramma in the western Gulf of Alaska. Mar Ecol Prog Ser 119:11-23

Barz K, Hirche HJ (2004) Predatory impact of Aurelia aurita on the zooplankton community in the Bornholm Basin (central Baltic). Int Counc Explor Sea CM 2004/J:12

Baumann H, Hinrichsen HH, Köster FW, Temming A (2004) A new retention index for the central Baltic Sea: long-term hydrodynamic modelling used to study recruitment variability in central Baltic sprat, Sprattus sprattus. Int Counc Explor Sea CM 2004/L:2

Belchier M, Clemmesen C, Cortes L, Doan T and 10 others (2004) Recruitment studies: manual on precision and accuracy of tools. ICES Tech Mar Environ Sci 33

Bretherton FP, Davis RE, Fandry CB (1976) A technique for objective analysis and design of oceanographic experiments applied to MODE-73. Deep-Sea Res 23:559-582

Bryan K (1969) A numerical method for the study of the circulation of the world ocean. J Phys Oceanogr 15:1312-1324

Buckley LJ (1979) Relationship between RNA-DNA ratio, prey density, and growth rate in Atlantic cod (Gadus morhua) larvae. J Fish Res Board Can 36:1497-1502

Buckley LJ (1984) RNA-DNA ratio: an index of larval fish growth in the sea. Mar Biol 80:291-298

Chicharo MA, Chicharo L, Valdés L, López-Jamar E, Ré P (1998) Estimation of starvation and diel variation of the RNA/DNA ratios in field-caught Sardina pilchardus larvae off the north of Spain. Mar Ecol Prog Ser 164:273-283

Clemmesen C (1993) Improvements in the fluorimetric determination of the RNA and DNA content of individual marine fish larvae. Mar Ecol Prog Ser 100:177-183 
Clemmesen C (1994) The effect of food availability, age or size on the RNA/DNA ratio of individually measured herring larvae: laboratory calibration. Mar Biol 118:377-382

Clemmesen C (1996) Importance and limits of RNA/DNA ratios as a measure of nutritional condition in fish larvae. In: Watanabe Y, Yamashita Y, Oozeki Y (eds) Survival strategies in early life stages of marine resources. Proceedings of an international workshop in Yokohama, 11-14 Oct 1994. Balkema, Rotterdam, p 67-82

Clemmesen C, Sanchez R, Wongtschowski C (1997) A regional comparison of nutritional condition of SW Atlantic anchovy larvae, Engraulis anchoita, based on RNA/DNA ratios. Arch Fish Mar Res 45:17-43

Clemmesen C, Bühler V, Carvalho G, Case R and 10 others (2003) Variability in condition and growth of Atlantic cod larvae and juveniles reared in mesocosms: environmental and maternal effects. J Fish Biol 62:706-723

Cox MD (1984) A primitive equation 3-dimensional model of the ocean. Tech Rep No. 1. Geophysical Fluid Dynamics Laboratory, Ocean Group, Princeton University, Princeton, NJ

Cury P, Roy C (1989) Optimal environmental window and pelagic fish recruitment success in upwelling areas. Can J Fish Aquat Sci 46:670-680

Cushing DH (1974) The natural regulation of fish populations. In: Harden Jones FR (ed) Sea fisheries research. Elek Science, London, p 399-412

Cushing DH (1990) Plankton production and year-class strength in fish populations: an update of the match/mismatch hypothesis. Adv Mar Biol 26:249-294

Cushing DH, Walsh JJ (1976) The ecology of the seas. Blackwell Scientific, Oxford

Dulcic J (1998) Larval growth of sprat, Sprattus sprattus phalericus, larvae in the northern Adriatic. Fish Res 36: $117-126$

Elwertowski J (1960) Biologische Grundlagen der Sprottenfischerei in der östlichen und mittleren Ostsee. FischForsch 3(4):1-19

Fortier L, Villeneuve A (1996) Cannibalism and predation on fish larvae by larvae of Atlantic mackerel, Scomber scombrus: trophodynamics and potential impact on recruitment. Fish Bull 94:268-281

Grimm SK, Herra T (1984) Spawning cycles of southern Baltic fishes based on surveys of eggs and larvae. Int Counc Explor Sea CM 1984/J:30

HELCOM (Baltic Environment Protection Commission, Helsinki Commission) (1993) First assessment of the state of the coastal waters of the Baltic Sea. Baltic Sea Environment Proceedings No 54

Hinrichsen HH, Möllmann C, Voss R, Köster FW, Kornilovs G (2002) Biophysical modeling of larval Baltic cod (Gadus morhua) growth and survival. Can J Fish Aquat Sci 59: 1858-1873

Hinrichsen HH, Böttcher U, Köster FW, Lehmann A, St John MA (2003a) Modelling the influences of atmospheric forcing conditions on Baltic cod early life stages: distribution and drift. J Sea Res 49:187-201

Hinrichsen HH, Lehmann A, Möllmann C, Schmidt JO (2003b) Dependancy of larval fish survival on retention/dispersion in food limited environments: the Baltic Sea as a case study. Fish Oceanogr 12:425-433

Hjort J (1914) Fluctuations in the great fisheries of Northern Europe viewed in the light of biological research. Rapp P-V Réun Cons Perm Int Explor Mer 160:1-228

Huwer B (2004) Larval growth of Sardina pilchardus and Sprattus sprattus in relation to frontal systems in the German Bight. Diploma thesis, University of Kiel
ICES (International Council for the Exploration of the Sea) (2004) Report of the Baltic Fisheries Assessment Working Group. Int Counc Explor Sea CM 2004/ACFM:18

Iles TD, Sinclair M (1982) Atlantic herring: stock discreteness and abundance. Science 215:627-633

Killworth PD, Stainforth D, Webbs DJ, Paterson SM (1991) The development of a free-surface Bryan-Cox-Semtner ocean model. J Phys Oceanogr 21:1333-1348

Kornilovs G, Sidrevics L, Dippner JW (2001) Fish and zooplankton interaction in the Central Baltic Sea. ICES J Mar Sci 58:579-588

Köster FW (1994) Der Einfluß von Bruträubern auf die Sterblichkeit früher Jugendstadien des Dorsches (Gadus morhua) und der Sprotte (Sprattus sprattus) in der zentralen Ostsee. Ber Inst Meereskde Kiel 261

Köster FW, Möllmann C (1997) Predation by sprat and herring on early life stages of cod and sprat in the central Baltic. In: Meyer RM (ed) Proc Symp Forage Fishes in Marine Ecosystems. Alaska Sea Grant College Program AK-SG-01. University of Alaska, Anchorage, AK, p 41-69

Köster FW, Möllmann C (2000a) Egg cannibalism in Baltic sprat Sprattus sprattus. Mar Ecol Prog Ser 196:269-277

Köster FW, Möllmann C (2000b) Trophodynamic control by clupeid predators on recruitment success in Baltic cod? ICES J Mar Sci 57:310-323

Köster FW, Schnack D (1994) The role of predation on early life stages of cod in the Baltic. Dana 10:179-201

Köster FW, Möllmann C, Neuenfeldt S, St John MA, Plikshs M, Voss R (2001) Developing Baltic cod recruitment models. I. Resolving spatial and temporal dynamics of spawning stock and recruitment for cod, herring, and sprat. Can J Fish Aquat Sci 58:1516-1533

Köster FW, Hinrichsen HH, Schnack D, St John MA and 7 others (2003) Recruitment of Baltic cod and sprat stocks: identification of critical life stages and incorporation of environmental variability into stock-recruitment relationships. Sci Mar 67:129-154

Kraus G, Mohrholz V, Voss R, Dickmann M, Hinrichsen HH, Herrmann JP (2004) Consequences of summer inflow events on the reproduction cycle of Baltic sprat. Int Counc Explor Sea CM 2004/L:19

Lehmann A (1995) A three-dimensional baroclinic eddyresolving model of the Baltic Sea. Tellus Ser A 47: 1013-1031

MacKenzie BR, Köster FW (2004) Fish production and climate: sprat in the Baltic Sea. Ecology 85:784-794

Meekan MG, Fortier L (1996) Selection for fast growth during the larval life of Atlantic cod Gadus morhua on the Scotian Shelf. Mar Ecol Prog Ser 137:25-37

Möllmann C, Köster FW (1999) Food consumption by clupeids in the Central Baltic: evidence for top-down control? ICES J Mar Sci 56(Suppl):100-113

Munk P (1993) Differential growth of larval sprat (Sprattus sprattus) across a tidal front in the eastern North Sea. Mar Ecol Prog Ser 99:17-29

Muus BJ, Nielsen JG (1999) Sea fish. Scandinavian Fishing Year Book, Hedehusene

Ochocki S, Mackiewiez T, Nakonieczny J, Zalewski M (1995) Primary production, chlorophyll, and qualitative and quantitative composition of phytoplankton in the Pomeranian Bay (southern Baltic). Bull Sea Fish Inst Gdynia 136: 33-42

Peck MA, Clemmesen C, Herrmann JP, Stäcker S, Temming A (2004) The feeding-growth relationship in post-larval Baltic sprat (Sprattus sprattus L.): comparison of somatic, nucleic acid- and otolith-based growth rates. Int Counc Explor Sea CM 2004/L:25 
Pepin P, Evans GT, Shears TH (1999) Patterns of RNA/DNA ratios in larval fish and their relationship to survival in the field. ICES J Mar Sci 56:697-706

Re P, Goncalves E (1993) Growth of sprat Sprattus sprattus larvae in the German Bight (North Sea) as inferred by otolith microstructure. Mar Ecol Prog Ser 96:139-145

Rooker JR, Holt GJ (1996) Application of RNA/DNA ratios to evaluate the condition and growth of larvae and juvenile red drum (Sciaenops ocellatus). Mar Freshw Res 47(2): 283-290

Rudstam LG, Aneer G, Hildén M (1994) Top-down control in the pelagic Baltic ecosystem. Dana 10:105-129

Semtner AJ (1974) A general circulation model for the World Ocean. Tech Rep No. 8. Department of Meteorology, University of California, Los Angeles, CA

Shields RJ (1989) Studies of growth and nutritional status in 0-group sprat, Sprattus sprattus (Clupeidae), using otolith microstructure and lipid analytical techniques. PhD thesis, University of Wales, Bangor

Sinclair M, Tremblay MJ (1984) Timing of spawning of Atlantic herring (Clupea harengus harengus) and the match/ mismatch theory. Can J Fish Aquat Sci 41:1054-1065

Sissenwine MP (1984) Why do fish populations vary? In: May RM (ed) Exploitation of marine communities. Springer, Berlin, p 59-94

Steedman HR (1976) Zooplankton fixation and preservation. Monogr Oceanogr Methodol 4:103-174

Editorial responsibility: Otto Kinne (Editor-in-Chief), Oldendorf/Luhe, Germany
Thompson BM, Milligan SP, Nichols JH (1981) The development rates of sprat (Sprattus sprattus) eggs over a range of temperatures. Int Counc Explor Sea CM 1981/H:15

Valenzuela GS, Vargas CA (2002) Comparative larval growth rate of Sprattus sprattus in relation to physical and biological oceanographic features in the North Sea. Arch Fish Mar Res 49:213-230

Voss R (2002) Recruitment processes in the larval phase: the influence of varying transport on cod and sprat larval survival. PhD thesis, University of Kiel

Voss R, Hinrichsen HH, St John M (1999) Variations in the drift of larval cod (Gadus morhua L.) in the Baltic Sea: combining field observations and modelling. Fish Oceanogr 8: 199-211

Voss R, Hinrichsen HH, Wieland K (2001) Model-supported estimation of mortality rates in Baltic cod (Gadus morhua callarias L.) larvae: the varying impact of critical periods. BMC (Biomed Central) Ecol 1:4, available at: http://www. biomedcentral.com/1472-6785/1/4

Voss R, Köster FW, Dickmann M (2003) Comparing the feeding habits of co-occuring sprat (Sprattus sprattus) and cod (Gadus morhua) larvae in the Bornholm Basin, Baltic Sea. Fish Res 63:97-111

Wieland K, Jarre-Teichmann A, Horbowa K (2000) Changes in the timing of spawning of Baltic cod: possible causes and implications for recruitment. ICES J Mar Sci 57: $452-464$

Submitted: January 7, 2005; Accepted: August 11, 2005 Proofs received from author(s): December 30, 2005 